\title{
Manajemen Asuhan Kebidanan Antenatal Care pada Ny "N" dengan Hiperemesis Gravidarum Tingkat III di Rsud Syekh Yusuf Gowa Tanggal 3 Juni-12 Juli 2019
}

\author{
${ }^{1}$ Irna Nisaulkhusna Kadir, ${ }^{2}$ Sitti Saleha, ${ }^{3}$ Nadyah
}

\begin{abstract}
ABSTRAK
Hiperemesis gravidarum adalah mual dan muntah berlebihan pada wanita hamil yang dapat mempengaruhi status kesehatan ibu dan tumbuh kembang janin sehingga penanganan dan pengobatan perlu segera diberikan. Pada Hiperemesis gravidarum tingkat III (Berat), Keadaan umum sangat parah, muntah berhenti, kesadaran sangat menurun, nadi kecil dan cepat, suhu meningkat, tensi menurun, dan ikterus. Komplikasi dapat berakibat fatal pada susunan syaraf pusat dan timbulnya ikterus menunjukkan adanya payah hati.
\end{abstract}

Karya Tulis ini bertujuan untuk melaksanakan Manajemen Asuhan Kebidanan Antenatal Care pada Ny"N"dengan Hiperemesis Gravidarum Tingkat III di RSUD Syekh Yusuf Gowa Tahun 2019 sesuai dengan 7 langkah Varney dan SOAP. pada kasus ini keadaan ibu kembali normal, serta tidak terjadi komplikasi pada ibu dan janin.

Kesimpulan dari Karya Tulis Ilmiah dengan 7 langkah Varney dan SOAP yang digunakan berdasarkan manajemen asuhan. Pada kasus ini proses penyelesaian masalah kebidanan telah dilaksanakan pengkajian berupa pemeriksaan dan analisa data pada Ny "N" dengan Hiperemesis Gravidarum Tingkat III di RSUD Syekh Yusuf Gowa tahun 2019, tindakan segera dan kolaborasi dilakukan untuk memperbaiki keadaan umum ibu serta proses pengobatan dan pemulihan sehingga kondisi ibu kembali normal. Telah dilakukan pendokumentasian semua temuan dan tindakan yang telah dilaksanakan pada $\mathrm{Ny}$ " $\mathrm{N}$ " dengan hasil tidak ditemukan kesenjangan antara teori dan kasus yang didapatkan.
*UIN Alauddin Makassar

*irnanisaulkhusna@gmail.com *hjstsaleha.uinmksr@gmail.com *nadyaharuna@gmail.com

Kata kunci :

Kehamilan;

Hiperemesis Gravidarum; 7 Langkah Varney

\section{PENDAHULUAN}

Mual muntah berlebihan merupakan salah satu komplikasi kehamilan yang mempengaruhi status kesehatan ibu dan tumbuh kembang janin, dimana kejadian ini dapat dideteksi dan dicegah pada masa kehamilan, mual dan muntah merupakan gangguan yang paling sering dijumpai pada kehamilan trimester I (Syamsuddin Syahril, 2018).

Pada kehamilan trimester I mual biasa terjadi pada pagi hari, malam hari bahkan setiap saat. Gejala-gejala ini terjadi kurang lebih 6 minggu setelah hari pertama haid terakhir dan berlangsung selama kurang lebih 10 minggu. Mual dan muntah terjadi pada 60-80\% primigravida dan 40-60\% multigravida. Perasaan mual ini disebabkan oleh karena 
meningkatnya kadar hormon esterogen dan Hormon Chorionic Gonadotropin (HCG). Keadaan inilah yang disebut dengan hiperemesis gravidarum (Dahlan, Andi Kasrida, 2017).

Hiperemesis gravidarum adalah mual dan muntah yang berlebihan pada wanita hamil sampai mengganggu pekerjaan sehari-hari karena umumnya menjadi buruk, karena terjadi dehidrasi. Penyebab hiperemesis gravidarum belum diketahui secara pasti, namun diperkirakan disebabkan oleh adanya peningkatan hormon estrogen dan Hormon Chorionic Gonadothrophin (HCG). Pada umumnya wanita dapat menyesuaikan diri dengan keadaan ini, meskipun demikian gejala mual dan muntah yang berat dapat berlangsung sampai 4 bulan. Sehingga, pekerjaan sehari-hari menjadi terganggu dan keadaan umum menjadi buruk (Nadyah, 2013: 38).

Kebutuhan nutrisi yang tidak terpenuhi pada ibu hamil akan berpengaruh pada janin, salah satunya adalah janin mengalami Berat Badan Lahir Rendah (BBLR). Hal ini disebabkan karena penurunan asupan zat besi, dan kurangnya pengetahuan ibu tentang pemeriksaan antenatal care (Indrayani, Triana.2018). Kurangnya kunjungan selama masa kehamilan dapat menyebabkan ibu memiliki sedikit informasi mengenai deteksi dini komplikasi atau gangguan yang terjadi selama masa kehamilan, salah satunya informasi mengenai hiperemesis gravidarum (Umboh hertje salome dkk, 2014). Antenatal Care terbukti mempunyai kedudukan yang sangat penting dalam upaya meningkatkan kesehatan mental dan fisik selama kehamilan untuk menghadapi persalinan. Pengawasan selama hamil dapat mengetahui berbagai komplikasi ibu yang mempengaruhi kehamilannya (Anasari,Tri. 2015).

Kehamilan dengan komplikasi mual muntah merupakan gejala yang umum terjadi pada sekitar 70\% sampai $85 \%$ dari seluruh kehamilan. Insidensi terjadinya kasus hiperemesis gravidarum sebesar 0,8\% sampai 3,2\% dari seluruh kehamilan atau sekitar 8 sampai 32 kasus per 1000 kehamilan (Nisak Ana Zumrotun dan Wigati Atun, 2018).

Kehamilan dengan hiperemesis gravidarum menurut World Health Organization (WHO) mencapai 12,5\% dari seluruh jumlah kehamilan di dunia dengan angka kejadian yang beragam yaitu mulai dari $0,3 \%$ di Swedia, $0,5 \%$ di California, $0,8 \%$ di Canada, $10,8 \%$ di China, $0,9 \%$ di Norwegia, 2,2\% di Pakistan, dan 1,9\% di Turki. Sedangkan angka kejadian hiperemesis gravidarum di Indonesia adalah mulai dari 1-3\% dari seluruh kehamilan (Maruroh dan Ikke R,2016:204). Kehamilan dengan komplikasi hiperemesis gravidarum 
berdasarkan data provinsi Sulawesi Selatan tahun 2018 dari 43 Puskesmas di Kota Makassar sebanyak 26.772 orang atau $62,99 \%$ (http://dinkes.sulselprov.go.id/\#).

Ibu hamil dengan komplikasi hiperemesis gravidarum berdasarkan data di RSUD Syekh Yusuf Gowa, pada tahun 2016 yaitu sebanyak 112 orang dengan hiperemesis gravidarum tingkat I sebanyak 76 orang, tingkat II sebanyak 29 orang, dan tingkat III sebanyak 7 orang, pada tahun 2017 terjadi peningkatan yaitu sebanyak 127 orang dengan hiperemesis gravidarum tingkat I sebanyak 68 orang, tingkat II sebanyak 49 orang, dan tingkat III sebanyak 10 orang, dan semakin meningkat pada tahun 2018 yaitu sebanyak 175 orang dengan hiperemesis gravidarum tingkat I sebanyak 92 orang, tingkat II sebanyak 65 orang dan tingkat III sebanyak 18 orang.

\section{METODE PENELITIAN}

Melaksanakan studi kasus dengan pendekatan Manajemen Asuhan Kebidanan sesuai dengan 7 langkahVarney dan pendokumentasian dalam bentuk SOAP. Penatalaksanaan Asuhan dilakukan dengan pemberian asuhan yang sesuai standar operasional prosedur pada kasus yang diteliti yaitu Manajemen Asuhan Kebidanan Antenatal Care dengan Hiperemesis Gravidarum Tingkat III.

\section{HASIL PENELITIAN DAN PEMBAHASAN}

\section{Langkah I (Pengumpulan Data Dasar)}

Pada studi kasus ini dilakukan pengkajian pada Ny "N". Dari hasil anamnesis, ibu mengatakan bahwa ia mengalami mual dan muntah sejak 2 bulan yang lalu. Ibu mengatakan bahwa sebelumnya ia sudah pernah dirawat di RSUD Syekh Yusuf Gowa dengan keluhan yang sama, yaitu pada tanggal 5-7 Mei 2019 dan pada saat itu ibu baru mengetahui bahwa dirinya sedang hamil dan usia kehamilan ibu adalah 9 minggu atau \pm 2 bulan.

Saat dirawat di RS, dilakukan pemeriksaan plano test dan hasilnya positif. Usia kehamilan ibu saat itu adalah 9 minggu atau sekitar 2 bulan jika dihitung dari HPHT (02-032019). Selain itu juga dilakukan pemeriksaan USG, dokter mengatakan tampak kantung kehamilan di dalam rahim ibu. Sehingga, bisa dipastikan bahwa ibu sedang hamil. Saat 
pulang dari RS, keluhan tersebut mulai berkurang, akan tetapi keluhan itu muncul kembali sejak 2 minggu yang lalu.

Ibu mengatakan bahwa ia muntah sekitar $\pm 5-6$ kali dalam sehari. Namun, keluhan ibu terus bertambah hingga mual dan muntah tersebut mencapai $\pm 10 \mathrm{kali} /$ hari, tetapi 2 hari yang lalu mual muntah ibu sudah mulai berkurang tetapi hal tersebut sangat mengganggu aktifitas. Ibu juga merasa pusing, lemas, nyeri ulu hati, dan berat badannya menurun dari $53 \mathrm{~kg}$ menjadi $50 \mathrm{~kg}$. Biasanya, ibu mual terlebih dahulu kemudian muntah setelah makan. Tekstur muntah yang keluar kadang air dan kadang makanan. Setiap selesai makan ibu langsung memuntahkan makanan tersebut, sehingga ibu menjadi malas makan. Mual dan muntah ini sangat menyiksa ibu hingga mengganggu aktifitas sehari-hari dan keadaan umumnya. Saat ini ibu berusia 22 tahun, ibu mengatakan bekerja sebagai ibu rumah tangga biasa yang mengerjakan pekerjaan sehari-hari sendiri.

Setelah dilakukan anamnesa, selanjutnya dilakukan pemeriksaan fisik. Dalam melakukan tindakan selalu diawali dengan berdoa dan mengucapkan basmalah. Keadaan umum ibu parah, kesadaran Samnolen (kondisi mengantuk yang cukup dalam tetapi masih bisa dibangunkan dengan rangsangan), turgor kulit jelek/buruk, BB ibu $50 \mathrm{~kg}$, tekanan darah 80/60 mmHg, mata tampak cekung, sklera sedikit ikterus, konjungtiva tampak pucat, bibir kering, dan lidah tampak kotor. Pada pemeriksaan abdomen, TFU 3 jari di atas simphysis, teraba ballottement $(+)$, dan tidak ada nyeri tekan. Berdasarkan rumus Naegle, usia kehamilan ibu dari hari pertama haid terakhir tanggal 2-03-2019 sampai tanggal pengkajian 03-06-2019 adalah 13 minggu 2 hari.

\section{Langkah II (Identifikasi Diagnosa atau Masalah Aktual)}

Kasus yang dialami oleh Ny "N", di mana mual muntah ibu mulai berhenti, kesadaran ibu menurun. Hal tersebut mengganggu aktifitas ibu dan mempengaruhi keadaan umumnya. Sehingga ibu dan keluarga memutuskan untuk ke RS agar diberikan penanganan yang tepat, karena ibu sudah sangat lemas dan tidak terlalu merespon. Selain itu, ibu juga merasa pusing dan nyeri ulu hati. Hasil pemeriksaan fisik yang dilakukan antara lain : tekanan darah ibu 80/60 mmHg, BB ibu $50 \mathrm{~kg}$ (BB sebelumnya $53 \mathrm{~kg}$ ), mata tampak cekung, konjungtiva pucat, sklera sedikit ikterus, bibir kering, dan lidah tampak kotor. 
Berdasarkan data diatas, Ny "N" di diagnosa mengalami hiperemesis gravidarum tingkat III. Ini sesuai dengan teori yang mengatakan bahwa ibu dengan hiperemesis gravidarum tingkat III karena keadaan umum ibu menjadi lebih parah, muntah berhenti, kesadaran menurun samnolen, nadi kecil dan cepat, suhu badan meningkat, serta tekanan darah menurun. Keadaan ini adalah akibat sangat kekurangan zat makanan, termasuk vitamin B kompleks. Timbulnya ikterus adalah tanda bahaya adanya payah hati (Marmi dkk, 2010: $55-56)$.

Setelah mengetahui diagnosa $\mathrm{ibu}$, segera dilakukan penanganan yang tepat dan menganjurkan suami dan keluarga ibu untuk selalu berdoa kepada Allah SWT agar dimudahkan dalam penyembuhan ibu. Dengan demikian dapat disimpulkan bahwa berdasarkan teori, hasil penelitian dan studi kasus tidak terdapat kesenjangan.

\section{Langkah III (Identifikasi Diagnosa atau Masalah Potensial)}

Berdasarkan data yang didapatkan pada Ny "N" dengan kasus hiperemesis gravidarum tingkat III, antisipasi masalah yang dapat terjadi pada ibu yaitu ikterus, terjadi perdarahan dari esofagus, lambung dan retina, serta tejadi komplikasi fatal pada susunan saraf dan apabila sepanjang kehamilan ibu menderita hiperemesis gravidarum hingga trimester ke III, maka kemungkinan bayinya mengalami BBLR, IUGR, Prematur hingga terjadi abortus. Anjurkan ibu dan keluarga untuk selalu berzikir, berdoa, mendengarkan lantunan ayat suci Al-Qur'an dan hal lain yang dapat mendekatkan diri kepada Allah SWT agar selalu diberikan kesehatan, dijauhkan dari rasa sakit sehingga tidak terjadi komplikasi yang semakin memperburuk kondisi ibu dan diberikan kesembuhan.

Dengan demikian berdasarkan hasil penelitian, penerapan teori dan manajemen asuhan kebidanan pada Ny "N"dengan studi kasus hiperemesis gravidarum tingkat III belum mengalami tanda bahaya tersebut tetapi harus segera dilakukan penanganan segera mungkin untuk mencegah terjadinya komplikasi yang akan terjadi karna apabila ibu tidak mendapatkan asuhan dan penanganan sedini mungkin kemungkinan besar ibu akan mengalami komplikasi dari hiperemesis gravidarum tingkat III. 


\section{Langkah IV (Tindakan Emergency atau Kolaborasi)}

Pada kasus Hiperemesis gravidarum tingkat III membutuhkan tindakan segera karna kondisi ibu sangat buruk dan tingkat kesadarannya sudah menurun pada kasus Ny "S", ibu mengalami dehidrasi berat yaitu kondisi dimana tubuh kita kehilangan cairan yang berlebihan yang disertai dengan gangguan proses metabolisme dalam tubuh sehingga tindakan segera yang dilakukan disini adalah memasang infus RL 28 tpm pada pukul 12.50 wita. Ini bertujuan untuk memperbaiki keadaan umum ibu. Selain itu, menganjurkan suami dan keluarga agar tetap berdoa kepada Allah SWT dan banyak berdzikir. Ini juga dapat membantu ibu agar tidak terlalu cemas dalam menghadapi keluhannya.

\section{Langkah V (Merencanakan Asuhan yang Menyeluruh)}

1. Telah dilaksanakan rencana asuhan atau intervensi pada $\mathrm{Ny}$ "N" yaitu melakukan rawat inap di RSUD Syekh Yusuf Gowa, melakukan kolaborasi dengan dokter mengenai tindakan dan pemberian obat, menganjurkan ibu makan makanan yang bernutrisi seperti mengandung karbohidrat dan protein yang tinggi, menganjurkan ibu untuk makan sedikit tapi sering, makan makanan selingan seperti biskuit dan roti kering, menganjurkan ibu agar banyak minum air putih, istirahat yang cukup, mengobservasi mual dan muntah, mengobservasi pengeluaran urine, mengobservasi tanda-tanda vital (TTV), serta memberikan dukungan psikologis dan spiritual agar senantiasa berdoa dan berdzikir kepada Allah SWT.

\section{Langkah VI (Implementasi)}

Implementasi yang dilakukan pada Ny"N" dengan kasus hiperemesis gravidarum tingkat III saat dirawat di RSUD Syekh Yusuf Gowa, kemudian dilanjutkan dengan kunjungan ke rumah pasien. Ny " $\mathrm{N}$ " dirawat selama 5 hari, yaitu mulai tanggal 3-7 Juni 2019. Pada hari pertama di RS yaitu tanggal 3 Juni 2019 ibu mengeluh mual dan muntah sebanyak \pm 10 kali semenjak 2 minggu yang lalu setiap makan dimuntahkan kembali dan sangat mengganggu aktifitas ibu, tetapi 2 hari yang lalu mual muntah ibu sudah mulai berkurang tetapi ibu merasa lemas, pusing, dan nyeri ulu hati. BB ibu turun dari $53 \mathrm{~kg}$ menjadi $50 \mathrm{~kg}$, TD : 80/60 mmHg, ibu merasa lemas, pusing, turgor kulit kurang baik, mata tampak cekung, sklera sedikit ikterus, konjungtiva pucat, bibir kering dan lidah tampak kotor. 
Maka asuhan yang diberikan yaitu, menyampaikan kepada ibu dan keluarga hasil pemeriksaan yang telah dilakukan, kemudian memberitahu ibu dan keluarga bahwa ibu harus segera dirawat inap karna kondisi ibu sangat buruk dan membahayakan apabila tidak ditangani segera.

Setelah itu, melakukan kolaborasi dengan dokter obgyn dalam melakukan tindakan dan pemberian obat, yaitu : memasang infus dengan cairan RL 28 tpm pada pukul 12. 50 wita, mengganti cairan RL menjadi cairan Ka-en MG 340 tpm pada pukul 13.30 wita, melakukan injeksi ranitidin dan ondasetron $1 \mathrm{amp} / \mathrm{IV} / 8$ jam pada pukul 14.00 wita, memberikan antasida sirup $3 \times 1 /$ oral pada pukul 14.00 wita, dan mengganti cairan Ka-en MG 3 menjadi Pan Amin G 40 tpm pada pukul 21.30 wita.

Selain itu, menganjurkan ibu untuk makan makanan yang bernutrisi selama kehamilan, makan dan minum dalam porsi sedikit tapi sering serta menghindari makanan dan minuman yang berbumbu atau berlemak, makan makanan selingan seperti biskuit dan roti kering, banyak minum air putih, istirahat yang cukup, dan menganjurkan ibu dan keluarga agar berdoa dan berdzikir kepada Allah SWT. Selanjutnya, mengobservasi mual dan muntah $( \pm 6$ kali), mengobservasi TTV pukul 18.00 WITA (TD: 100/60 mmHg, nadi: $80 \mathrm{x} / \mathrm{menit}$, suhu : $37,5^{\circ} \mathrm{C}$, dan pernapasan : $\left.20 \mathrm{x} / \mathrm{menit}\right)$. Serta mengobservasi pengeluaran urine $( \pm 150 \mathrm{ml})$.

Pada hari kedua yaitu pada tanggal 4 Juni 2019, ibu masih mual dan muntah, sedikit pusing dan masih nyeri ulu hati, keadaan umum masih lemah, TD 100/70 mmHg, turgor kulit kurang baik, wajah masih pucat, mata masih cekung, bibir tampak kering, dan lidah masih agak kotor. Asuhan yang diberikan adalah menyampaikan kepada ibu dan keluarga hasil pemeriksaan bahwa kondisi ibu sudah lebih baik dari sebelumnya, memantau pemberian cairan dan obat-obatan, yaitu : mengganti cairan Pan Amin G menjadi cairan RL dengan drips Neurobion $1 \mathrm{amp} / 24$ jam, 28 tpm pada pukul 05.00 wita, melakukan injeksi ranitidin dan ondansetron $1 \mathrm{amp} / \mathrm{IV} / 8$ jam serta memberikan antasida sirup (3x1/ oral) pada pukul $06.00,14.00$, dan 22.00 wita.

Selain itu, memberitahu ibu agar tidak menggunakan pakaian yang ketat, mengobservasi muntah ( \pm 4 kali), mengobservasi TTV pada pukul 08.00 WITA (TD : 100/70 mmHg, nadi: $78 \mathrm{x} /$ menit, suhu: $37,2^{\circ} \mathrm{C}$, pernapasan : $24 \mathrm{x} /$ menit), pukul 12.00 WITA (TD : 100/70mmHg, nadi : $82 \mathrm{x} / \mathrm{menit}$, suhu $: 36,5^{\circ} \mathrm{C}$, pernapasan : $21 \mathrm{x} / \mathrm{menit}$ ), dan pada pukul 
18.00 WITA (TD: $110 / 70 \mathrm{mmHg}$, nadi : $80 \mathrm{x} /$ menit, suhu : $36,8^{\circ} \mathrm{C}$, pernapasan : $22 \mathrm{x} / \mathrm{menit}$ ). Mengobservasi pengeluaran urine $( \pm 250 \mathrm{ml})$,

Pada hari ketiga yaitu tanggal 5 Juni 2019, ibu masih sedikit mual dan muntah semakin berkurang, ibu berusaha untuk makan walaupun sedikit, ibu masih sedikit pusing, nyeri ulu hati yang dirasakan mulai berkurang, keadaan umum masih lemah, turgor kulit mulai baik, TD 100/70 mmHg, wajah tampak segar, matatidak cekung, bibir lembab, dan lidah tampak bersih. Asuhan yang diberikan adalah menyampaikan kepada ibu dan keluarga hasil pemeriksaan bahwa kondisi ibu sudah mulai membaik, memantau pemberian cairan dan obat : memasang infus cairan RL drips neurobion/24 jam 28 tpm pada pukul 05.00 wita, melakukan injeksi ranitidin dan ondansetron $1 \mathrm{amp} / \mathrm{IV} / 8$ jam serta memberikan antasida sirup (3x1/ oral) pada pukul $06.00,14.00$, dan 22.00 wita, mengobservasi muntah ( \pm 2 kali), mengobservasi TTV pada pukul 08.00 wita (TD :110/70 $\mathrm{mmHg}$, nadi :80 x/menit, suhu : $36,8^{\circ} \mathrm{C}$. pernapasan: $22 \mathrm{x} / \mathrm{menit}$ ), pukul 12.00 wita (TD: $100 / 70 \mathrm{mmHg}$, nadi $: 86 \mathrm{x} / \mathrm{menit}$, suhu : $36,5^{\circ} \mathrm{C}$, pernapasan : $22 \mathrm{x} / \mathrm{menit}$ ), dan pukul 18.00 wita (TD: $110 / 70 \mathrm{mmHg}$, nadi : 78 $\mathrm{x} / \mathrm{menit}$, suhu : $36,7^{\circ} \mathrm{C}$, pernapasan : $20 \mathrm{x} /$ menit).

Pada hari keempat yaitu tanggal 6 Juni 2019, ibu masih sedikit mual dan muntah semakin berkurang, nafsu makan sudah membaik dan mulai banyak minum air putih, tidak terlalu pusing, keadaan umum baik, turgor kulit mulai baik, TD 100/70 mmHg, mata tidak cekung, bibir lembab, dan lidah tampak bersih. Asuhan yang diberikan adalah menyampaikan kepada ibu dan keluarga hasil pemeriksaan bahwa kondisi ibu sudah mulai membaik, memantau pemberian cairan dan obat : memasang infus cairan RL drips neurobion/24 jam 28 tpm pada pukul 05.00 wita, melakukan injeksi ranitidin dan ondansetron $1 \mathrm{amp} / \mathrm{IV} / 8$ jam serta memberikan antasida sirup $(3 \times 1 /$ oral $)$ pada pukul $06.00,14.00$, dan 22.00 wita, mengobservasi muntah ( \pm 2 kali), mengobservasi TTV pada pukul 08.00 wita (TD :110/70 mmHg, nadi $: 80 \mathrm{x} /$ menit, suhu : $36,8^{\circ} \mathrm{C}$. pernapasan: $22 \mathrm{x} /$ menit), pukul 12.00 wita (TD: 100/70mmHg, nadi :86 x/menit, suhu : $36,5^{\circ} \mathrm{C}$, pernapasan : $22 \mathrm{x} /$ menit), dan pukul 18.00 wita (TD: $110 / 70 \mathrm{mmHg}$, nadi : $78 \mathrm{x} /$ menit, suhu : $36,7^{\circ} \mathrm{C}$, pernapasan : $20 \mathrm{x} /$ menit).

Kemudian, pada tanggal 7 Juni 2019, ibu sudah dibolehkan untuk pulang karena mual muntah sudah semakin berkurang, tidak lagi merasa pusing dan nyeri ulu hati, keadaan umum dan TD 110/70 mmHg. Turgor kulit sudah baik, wajah ibu tampak segar, mata tidak cekung, 
konjungtiva merah muda, sklera tidak ikterus, bibir lembab, dan lidah tampak bersih. BB : 51 $\mathrm{kg}$, LILA : 23,5 cm, dan TFU : 3 jari di atas simphysis. Asuhan yang diberikan yaitu: mengganti cairan RL drips neurobion dengan cairan RL pada pukul 05.00 wita, mengobservasi TTV pada pukul 08.00 wita(TD :110/70 $\mathrm{mmHg}$, nadi: $78 \mathrm{x} / \mathrm{menit}$, suhu : $36,5^{\circ} \mathrm{C}$, pernapasan : $20 \mathrm{x} /$ menit), dan melakukan aff infus pada pukul 06.25 wita.

Selain itu, memberikan konseling pada ibu agar tidak terlalu memikirkan mual dan muntahnya, perasaan tersebut memang tidak langsung berhenti. Tetapi bertahap seiring berjalannya kehamilan dan biasanya akan berhenti di akhir trimester kedua atau usia kehamilan \pm 4 bulan, menganjurkan ibu untuk makan sedikit tapi sering agar kebutuhan nutrisi ibu dan janin dapat terpenuhi, makan makanan yang bergizi serta tidak makan makanan yang dapat memicu mual muntah. Seperti makanan berbumbu, berlemak, dan sebagainya. Memberitahu ibu agar istirahat yang cukup, tidak melakukan aktifitas yang berat, tidak banyak pikiran, termasuk memikirkan kehamilannya yang sekarang karena ibu belum pernah mengalaminya sebelumnya sehingga membuat ibu belum siap dengan perubahan yang terjadi. Hal ini juga dapat memicu terjadinya mual muntah.

Menganjurkan ibu untuk menjaga kebersihan diri agar ibu bisa nyaman dalam menjalani kehamilannya, menganjurkan ibu agar sering berdzikir dan berdoa kepada Allah SWT agar diberikan kesehatan dan kelancaran hingga persalinannya nanti. Serta memberitahu ibu agar tidak menjadikan ini sebagai beban karena kehamilan merupakan anugrah dan amanah dari Allah.Memberikan obat oral pada ibu dan dianjurkan untuk diminum tepat waktu sesudah makan, yaitu vitamin B6 (3x1), antasida tablet (3x1), dan tablet Fe (1x1), serta menganjurkan ibu agar segera ke RS jika mengalami keluhan.

Setelah ibu pulang dari RS, asuhan dilanjutkan dengan melakukan kunjungan rumah sebanyak 5 kali kunjungan. Pada kunjungan pertama tanggal 14 Juni 2019, ibu sudah tidak pernah muntah tapi masih mual, TTV normal (TD : 110/80 mmHg, nadi : 80x/menit, suhu : $36,5^{\circ} \mathrm{C}$, dan pernapasan : $22 \mathrm{x} /$ menit). Asuhan yang diberikan yaitu :memberitahu ibu agar tidak memaksa dirinya untuk beraktifitas dirumah, cukup melakukan hal yang dianggap mampu dilakukan agar tidak kelelahan, menganjurkan ibu agar istirahat yang cukup, yaitu tidur siang 1-2 jam perhari, dan tidur malam 6-8 jam perhari, banyak minum air putih agar 
ibu tidak dehidrasi, dan mengonsumsi tablet Fe untuk mencegah terjadinya anemia, yaitu 1 tablet dalam sehari sebelum tidur.

Selain itu, memberitahu ibu agar tidak menggunakan pakaian yang ketat, memberikan dukungan psikologis pada ibu agar optimis menghadapi kehamilannya dengan cara ikhlas menghadapinya, tidak menjadikan keluhan sebagai beban sehingga tidak menyukai jika dirinya hamil. Karena sesungguhnya Allah yang menciptakan sakit itu ada dan Allah pula yang memberikan kesembuhan, menjelaskan kepada ibu bahwa di trimester kedua kehamilan biasanya terjadi haemodelusi atau pengenceran darah. Jadi, ibu harus makan makanan yang bergizi untuk memenuhi kebutuhan dirinya dan janinnya, juga untuk memenuhi kebutuhan zat besi yang dibutuhkan agar tidak terjadi anemia, serta menganjurkan ibu agar selalu berdoa dan berdzikir kepada Allah agar diberikan kesehatan dan kenyamanan dalam menjalani kehamilannya hingga persalinan.

Kunjungan kedua dilakukan pada tanggal 21 Juni 2019, ibu masih mual jika mencium bau makanan yang menyengat dan berbumbu dan sudah tidak memuntahkan makanan yang dimakan, TTV normal (TD : 110/80 mmHg, nadi : 88x/ menit, suhu : 36,5 ${ }^{\circ} \mathrm{C}$, dan pernapasan : 20x/menit), BB : $52 \mathrm{~kg}$, LILA : $24 \mathrm{~cm}$, dan TFU : pertengahan simphysis-pusat. Asuhan yang diberikan yaitu :memberitahu ibu agar menghindari makanan yang berbau menyengat, berlemak dan berbumbu hingga keadaan ibu benar-benar membaik, tetap makan dengan porsi sedikit tapi sering, makan makanan yang mengandung karbohidrat dan protein yang tinggi, selalu berdoa dan berdzikir kepada Allah SWT agar diberikan kesehatan selama kehamilan hingga persalinannya, dan menganjurkan ibu untuk mengonsumsi tablet Fe untuk mencegah terjadinya anemia, yaitu 1 tablet dalam sehari sebelum tidur.

Kunjungan ketiga dilakukan pada tanggal 28 Juni 2019, ibu masih sedikit mual jika mencium bau makanan yang menyengat dan berbumbu, tapi sudah tidak pernah muntah, TTV normal (TD : 110/70 $\mathrm{mmHg}$, nadi : 86x/ menit, suhu : 37,5 $5^{\circ} \mathrm{C}$, dan pernapasan : 20x/menit), BB ibu naik menjadi 52,5 kg. Asuhan yang diberikan yaitu : memberitahu ibu bahwa mual dan muntah ibu akan berhenti secara bertahap seiring dengan bertambahnya usia kehamilan dan kemampuan ibu beradaptasi kembali dengan kehamilannya, tetap mengonsumsi tablet $\mathrm{Fe}$ yang diberikan oleh bidan, yaitu 1 tablet sebelum tidur. 
Selain itu, menganjurkan ibu agar tetap menjaga pola makannya agar dapat memenuhi kebutuhan ibu dan janin dengan mengkonsumsi makanan yang mengandung gizi tinggi, seperti mengandung karbohidrat, protein, vitamin dan mineral, serta memberitahu ibu agar tetap menjaga pola istirahatnya, serta menghindari makanan yang dapat memicu mual. Seperti makanan berbumbu dan berlemak, dan memberitahu ibu agar selalu berdoa kepada Allah SWT dan memperbanyak dzikir.

Kunjungan keempat dilakukan pada tanggal 05 Juli 2019, ibu sudah tidak mual dan muntah, TTV normal (TD : 110/70 $\mathrm{mmHg}$, nadi : 82x/ menit, suhu : $37,5^{\circ} \mathrm{C}$, dan pernapasan : 22x/menit), BB ibu semakin bertambah dari $52,5 \mathrm{~kg}$ menjadi $53,5 \mathrm{~kg}$, dan LILA juga bertambah dari $24 \mathrm{~cm}$ menjadi $24,5 \mathrm{~cm}$. Asuhan yang diberikan yaitu : memberitahu ibu agar tetap menjaga pola makannya dan makan makanan yang bergizi, banyak minum air putih agar tidak dehidrasi, istirahat yang cukup, dan memberitahu ibu agar segera ke pusat pelayanan kesehatan jika mengalami kelainan atau jika ada keluhan.

Kunjungan rumah kelima (terakhir) dilakukan pada tanggal 12 Juli 2019, ibu sudah tidak memiliki keluhan, sudah merasa sehat dan dapat beraktifitas seperti biasanya, TTV normal (TD : 110/80 $\mathrm{mmHg}$, nadi : 86x/menit, suhu: $37,5^{\circ} \mathrm{C}$, dan pernapasan : 22x/menit), BB ibu : 53,5 kg, LILA : 24,5 cm, dan TFU: 3 jari di bawah pusat. Asuhan yang diberikan : memberitahu ibu agar tetap menjaga pola makannya dan makan makanan yang bergizi seimbang, yaitu mengandung karbohidrat dan protein tinggi. Karbohidrat seperti nasi, jagung, roti, kentang, dan sebagainya. Sedangkan makanan yang mengandung protein seperti daging, ikan, telur, susu, tahu, tempe, sayuran hijau, kacang-kacangan, dan sebaginya.

Selain itu, memberitahu ibu untuk memperbanyak minum air putih agar tidak dehidrasi, menganjurkan ibu untuk istirahat yang cukup dan tidak melakukan aktifitas yang berat, menganjurkan ibu untuk melakukan USG guna melihat pertumbuhan dan perkembangan janin, serta memberitahu ibu agar segera ke pusat pelayanan kesehatan jika mengalami kelainan atau keluhan.

Pada langkah ini penulis tidak memiliki hambatan dalam memberikan asuhan kebidanan karena seluruh tindakan yang dilakukan telah mengarah dan sesuai dengan kebutuhan pasien. Serta pasien dan keluarga pasien dapat bekerja sama dengan baik dalam pelaksanaan pemberian asuhan kebidanan. 


\section{Langkah VII (Evaluasi)}

Setelah dilakukan asuhan kebidanan pada Ny "N"dengan hiperemesis grvidarum tingkat III selama 10x kunjungan. Pada hari pertama di RS yaitu tanggal 3 Juni 2019 ibu mengeluh mual dan muntah sebanyak \pm 10 kali semenjak 2 minggu yang lalu setiap makan dimuntahkan kembali dan sangat mengganggu aktifitas ibu, tetapi 2 hari yang lalu mual muntah ibu sudah mulai berkurang tetapi ibu merasa lemas, pusing, dan nyeri ulu hati. BB ibu turun dari $53 \mathrm{~kg}$ menjadi $50 \mathrm{~kg}$, TD : 80/60 mmHg, ibu merasa lemas, pusing, turgor kulit jelek, mata tampak cekung, sklera sedikit ikterus, konjungtiva pucat, bibir kering dan lidah tampak kotor

Pada hari kedua yaitu pada tanggal 4 Juni 2019, ibu masih mual dan muntah sebanyak \pm 4 kali, sedikit pusing dan masih nyeri ulu hati, keadaan umum masih lemah, TD : 100/70 $\mathrm{mmHg}$, turgor kulit mulai baik, wajah masih pucat, mata masih cekung, bibir tampak kering, dan lidah masih agak kotor.

Pada hari ketiga yaitu tanggal 5 Juni 2019, ibu masih sedikit mual danmuntah semakin berkurang, yaitu \pm 3-4 kali, nafsu makan sudah mulai membaik dan mulai banyak minum air putih, tidak terlalu pusing, keadaan umum masih lemah, turgor kulit mulai baik, TD: 110/70 mmHg, wajah tampak segar, mata masih cekung, bibir tampak kering, dan lidah masih agak kotor.

Pada hari keempat yaitu tanggal 6 Juni 2019, ibu masih sedikit mual danmuntah semakin berkurang, yaitu $\pm 1-2$ kali, nafsu makan sudah mulai membaik dan mulai banyak minum air putih, tidak terlalu pusing, keadaan umum baik, turgor kulit mulai baik, TD: 110/70 mmHg, mata masih cekung, bibir lembab, dan lidah tampak bersih.

Kemudian, pada tanggal 7 Juni 2019, ibu sudah dibolehkan untuk pulang karena mual muntah sudah semakin berkurang, tidak lagi merasa pusing dan nyeri ulu hati, keadaan umum dan TD: 110/70 mmHg.BB $51 \mathrm{~kg}$, LILA 23,5 cm, TFU 3 jari di atas simphysis, turgor kulit sudah baik, wajah ibu tampak segar, mata tidak cekung, konjungtiva merah muda, sklera tidak ikterus, bibir lembab, dan lidah tampak bersih.

Setelah ibu pulang dari RS, asuhan dilanjutkan dengan melakukan kunjungan rumah sebanyak 5 kali kunjungan. Pada kunjungan pertama yaitu pada tanggal 14 Juni 2019, ibu 
sudah tidak pernah muntah tapi masih mual, TTV(TD : 110/80 mmHg, nadi : 80x/ menit, suhu : $36,5^{\circ} \mathrm{C}$, dan pernapasan : 22x/menit), BB $52 \mathrm{~kg}$, LILA 23,5 $\mathrm{cm}$, TFU 3 jari di atas simphysis, turgor kulit baik, dan wajah ibu tampak segar.

Kunjungan kedua dilakukan pada tanggal 21 Juni 2019, ibu masih mual jika mencium bau makanan yang menyengat dan berbumbu dan sudah tidak memuntahkan makanan yang dimakan, nafsu makan mulai membaik, mulai beraktifitas di rumah meskipun belum seperti biasanya,TTV(TD : 110/80 $\mathrm{mmHg}$, nadi : 88x/ menit, suhu : $36,5^{\circ} \mathrm{C}$, dan pernapasan : 20x/menit), BB : $53 \mathrm{~kg}$, LILA : $24 \mathrm{~cm}$, dan TFU : pertengahan simphysis-pusat.

Kunjungan ketiga dilakukan pada tanggal 28 Juni 2019, ibu masih sedikit mual jika mencium bau makanan yang menyengat dan berbumbu, tapi sudah tidak pernah muntah, sudah mulai mampu melakukan aktifitas di rumah, TTV(TD : 110/70 mmHg, nadi : 86x/ menit, suhu : $37,5^{\circ} \mathrm{C}$, dan pernapasan : 20x/menit), BB naik dari $52 \mathrm{~kg}$ menjadi $53 \mathrm{~kg}$.

Kunjungan keempat dilakukan pada tanggal 05 Juli 2019, ibu sudah tidak mual dan muntah, nafsu makan semakin bertambah dan tidak lagi memilih makanan yang ingin dimakan,sudah mampu melakukan aktifitas seperti biasa, TTV(TD : 110/70 mmHg, nadi : $82 \mathrm{x} /$ menit, suhu : $37,5^{\circ} \mathrm{C}$, dan pernapasan : 22x/menit),BB ibu semakin bertambah dari $53 \mathrm{~kg}$ menjadi $53,5 \mathrm{~kg}$, dan LILA $24 \mathrm{~cm}$.

Kunjungan rumah kelima (terakhir) dilakukan pada tanggal 12 Juli 2019, ibu sudah tidak memiliki keluhan mual dan muntah, sudah merasa sehat dan dapat beraktifitas seperti biasanya, TTV(TD : 110/80 $\mathrm{mmHg}$, nadi : 86x/ menit, suhu : 37,5 $5^{\circ}$, dan pernapasan : 22x/menit), BB ibu : 53,5 kg, LILA : $24 \mathrm{~cm}$ dan TFU : 3 jari di bawah pusat.

Setelah dilakukan asuhan kebidanan di RS maupun kunjungan di rumah pasien, tidak ditemukan adanya kesenjangan antara teori dan kasus, tidak ada kelainan maupun komplikasi dari hiperemesis gravidarum tingkat III itu sendiri. Ibu sudah tidak mengalami mual dan muntah lagi, merasa sehat dan sudah mampu melakukan aktifitas sehari-hari seperti biasanya. Sehingga ibu sudah mulai merasa nyaman dalam menjalani kehamilannya. Hal tersebut terjadi karena manajemen asuhan yang diberikan sesuai dengan teori dan wewenang bidan serta tenaga kesehatan lainnya. Hal ini tentunya tidak terlepas dari izin Allah SWT yang senantiasa memberikan kebaikan berupa nikmat kesembuhan dan kesehatan bagi ummatnya 
yang meminta pertolongan kepada-Nya, percaya dan yakin pada Allah bahwa setiap penyakit mempunyai obat. Sehingga hendaknya kita untuk selalu bersyukur dan memperbanyak doa dan dzikir

\section{KESIMPULAN DAN SARAN}

\section{A. KESIMPULAN}

1. Telah dilaksanakan pengkajian dan analisis data sehingga ditemukan data subjektif dan objektif pada Ny "N". Data subjektif yang ditemukan yaitu ibu mengeluh mual dan muntah sebanyak \pm 10 kali dalam sehari sejak 2 minggu yang lalu tetapi 2 hari yang lalu mual muntah ibu sudah mulai berkurang tetapi mengganggu aktifitas dan keadaan umum ibu, ibu memuntahkan semua makanan yang dimakan sehingga ibu menjadi malas makan, ibu merasa lemas, serta nyeri ulu hati. Sedangkan data objektifnya yaitu keadaan umum lemah, kesadaran samnolen, turgor kulit jelek, tekanan darah 80/60 mmHg, mata cekung, sklera sedikit ikterus, konjungtiva pucat, bibir kering, dan lidah tampak kotor.

2. Telah dirumuskan diagnosa/ masalah aktual pada Ny "N" di RSUD Syekh Yusuf Gowa berdasarkan interpretasi data yang telah dilakukan, yaitu GI P0 A0, gestasi 1315 minggu, intrauterin, tunggal, keadaan ibu lemah dengan hiperemesis gravidarum tingkat III.

3. Telah dirumuskan diagnosa/ masalah potensial pada $\mathrm{Ny}$ "N" dengan hiperemesis gravidarum tingkat III di RSUD Syekh Yusuf Gowa, yaitu dapat terjadi dehidrasi berat, ikterik, takikardia, suhu meningkat, alkalosis, adanya nistagmus, diplopia, gangguan emosional yang berhubungan dengan kehamilan, keluarga, menarik diri, hingga depresi serta gangguan pertumbuhan dan perkembangan janin. Namun, pada kasus ini diagnosa potensial atau komplikasi tersebut tidak terjadi karena telah seger diberikan asuhan, penanganan dan pemantauan yang sesuai, sehingga kondisi ibu bisa membaik

4. Telah dilaksanakan perlunya tindakan segera pada $\mathrm{Ny}$ "N" dengan hiperemesis gravidarum tingkat III di RSUD Syekh Yusuf Gowa, yaitu memasang infus RL 28 tpm pada pukul 12.50 wita, ini berguna untuk memperbaiki keadaan umum ibu dan membantu mengganti cairan tubuh yang hilang. 
5. Telah dilaksanakan rencana asuhan atau intervensi pada $\mathrm{Ny}$ "N" yaitu melakukan rawat inap di RSUD Syekh Yusuf Gowa, melakukan kolaborasi dengan dokter mengenai tindakan dan pemberian obat, menganjurkan ibu makan makanan yang bernutrisi seperti mengandung karbohidrat dan protein yang tinggi, menganjurkan ibu untuk makan sedikit tapi sering, makan makanan selingan seperti biskuit dan roti kering, menganjurkan ibu agar banyak minum air putih, istirahat yang cukup, mengobservasi mual dan muntah, mengobservasi pengeluaran urine, mengobservasi tanda-tanda vital (TTV), serta memberikan dukungan psikologis dan spiritual agar senantiasa berdoa dan berdzikir kepada Allah SWT.

6. Telah dilaksanakan asuhan atau implementasi pada $\mathrm{Ny}$ " $\mathrm{N}$ " dengan hiperemesis gravidarum tingkat III di RSUD Syekh Yusuf Gowa sesuai dengan rencana asuhan yang telah disusun dan sesuai syariat islam. Seperti berdoa dan memperbanyak dzikir kepada Allah SWT saat melakukan tindakan agar senantiasa diberikan kemudahan dalam membantu proses penyembuhan ibu.

7. Telah dilaksanakan evaluasi terhadap hasil asuhan yang telah dilakukan pada $\mathrm{Ny}$ "N" dengan hiperemesis gravidarum tingkat III di RSUD Syekh Yusuf Gowa, tidak ditemukan adanya kelainan maupun komplikasi. Sehingga ibu dapat menjalani kehamilannya dengan sehat dan nyaman serta hiperemesis gravidarum yang dialami oleh ibu dapat diatasi.

8. Telah dilaksanakan pendokumentasian terhadap semua temuan dan tindakan yang telah diberikan pada Ny "N" dengan hiperemesis gravidarum tingkat III di RSUD Syekh Yusuf Gowa.

\section{B. SARAN}

Melihat besarnya efek yang ditimbulkan pada kasus hiperemesis gravidarum tingkat III yang berdampak buruk baik pada ibu dan janin, maka perlu diberikan tindakan yang tepat dan segera untuk mengatasi masalah tersebut. Oleh karena itu, adapun penulis sarankan sebagai berikut:

1. Bagi Prodi Kebidanan

Diharapkan agar prodi kebidanan semakin meningkatkan mutu dan kualitas pembelajaran bagi mahasiswa. Sehingga mahasiswa dapat menerapkan hal tersebut di 
lahan praktik serta memberikan asuhan yang tepat sehingga dapat mengantisipasi terjadinya komplikasi. Termasuk pada kasus hiperemesis gravidarum tingkat III.

2. Bagi Tenaga Kesehatan

Diharapkan agar tenaga kesehatan khususnya bidan mampu memberikan asuhan kebidanan yang tepat dan sesuai wewenangnya dalam menghadapi kasus hiperemesis gravidarum tingkat III dengan tetap menerapkan integrasi keislaman di dalamnya.

3. Bagi Penulis

Diharapkan agar penulis semakin meningkatkan wawasan keilmuan dan pengalaman yang dimiliki agar semakin mahir dalam menangani kasus kebidanan, termasuk pada kasus hiperemesis gravidarum tingkat III

4. Bagi Ibu dan Keluarga

a. Diharapkan agar dapat menambah pengetahuan ibu hamil terkait hal-hal yang bisa terjadi selama kehamilan, termasuk kasus hiperemesis gravidarum tingkat III yang dapat membahayakan ibu dan janin.

b. Diharapkan ibu dapat mengenali kelainan atau tanda bahaya pada ibu hamil dan segera ke pusat pelayanan kesehatan jika mengalaminya. Dengan demikian, dapat diberikan penanganan secepat mungkin dan mencegah terjadinya komplikasi.

c. Diharapkan agar ibu banyak berdoa dan berdzikir kepada Allah SWT agar senantiasa diberikan kesehatan dan kemudahan selama kehamilan hingga persalinnya nanti.

d. Diharapkan agar keluarga dapat membantu proses penyembuhan ibu dengan hiperemesis gravidarum. Seperti memberikan support dan menjaga kondisi psikologis ibu sehingga ibu dapat menjalani kehamilannya dengan nyaman

\section{DAFTAR PUSTAKA}

Agustina Wulandari, S. T. (2018). Penatalaksanaan Ibu Hamil Dengan Hiperemesis Gravidarum Di Rumah Sakit Umum Daerah Wonogiri. Indonesian Journal On Medical Science, 149-155.

Ahila, A. (2013). Severe Hyperemesis Gravidarum Affects Offspring Metabolism In Childhood. International Journal Of Pediatric Endocrinology , 10-11.

Alvenia Lia, S. (2016). Upaya Peningkatan Kebutuhan Nutrisi Pada Pasien Hiperemesis Gravidarum Di RSU Assalam Gemolong. 1-13.

Ardani Ayu, "Perbandingan Efektifitas Pemberian Terapi Minuman Jahe dan Minuman Kapulaga Terhadap Morning Sickness pada Trimester I di Kelurahan Ngempon Kecamatan Bergas Kabupaten Semarang”, 2016. 
Armiati, N. (2018). Hubungan Antara Hiperemesis Gravidarum Dengan Berat Badan Lahir Bayi Di RSUD Haji Makassar. Jurnal Mitrasehat,Volume VII Nomor 1 , 9-17.

Aquari Bina, "Faktor-faktor yang Mempengaruhi Kejadian Hiperemesis gravidarum (HEG) di Puskesmas Sosial Palembang Tahun 2017”, Akademi Kebidanan Budi Mulia Palembang, Vol 5 No 1, Juni 2017.

Dagmar, K. (2016). Seltene Folge einer Hyperemesis Gravidarum. Obstetri Gynecol1.

Dahlan Andi Kasrida, U. a. (2017). Faktor yang berhubungan dengan pengetahuan ibu hamil primigravida dalam pengenalan tanda bahaya kehamilan. Jurnal Voice of Midwifery, Vol 07 No.09, 1-14.

Darmawansyih, 2014. Penyakit Kronik dalam Kehamilan. Makassar: Alauddin University Press

Departemen Kesehatan RI 2018. Peta Kesehatan Indonesia. Jakarta: Depkes RI.

Dewi. 2012. Asuhan Keperawatan Pada Klien dengan Hiperemesis Gravidarum:Penerapan Konsep dan Teori. Jakarta: Salemba Medika

Fajar, Hajriah dan Suharyanto. Aplikasi Pengetahuan Kehamilan Dan Perhitungan Masa Kehamilan Berbasis Android Menggunakan Metode Algoritma Naegele. Jurnal Ilmu Pengetahuan Dan Teknologi Komputer Volume4Nomor2,Februari2019.ejournal.nusamandiri.ac.id/ejurnal/index.php/jitk/article/vie w/951. (Diakses tanggal 22 juni 2019).

Fauziyah Yulia. (2012). Obstetri Patologi. Yogyakarta:Nusa Medika

Grooten Iris J, d. (2016). Early nasogastric tube feeding in optimising treatment for hyperemesis gravidrum: the MOTHER randomised controlled trial (Maternal and Offspiring outcomes after Treatment of HyperEmesis by Refeeding). BMC Pregnancy and Childbirth, 1-6.

Handayani Sri, A. U. (2018). Analis Kejadian Hiperemesis Gravidarum (HEG) Berdasarkan Karakteristiknya. Babul Ilmi_Jurnal Ilmiah Multi Science Kesehatan , 99-108.

Hidayati Ratna. (2018). Asuhan Keperawatan pada Kehamilan Fisiologi dan Patologis. Jakarta: Salemba Medika.

http://dinkes.sulselprov.go.id/\#

Indrayani Triana. 2018. Asuham Kebidanan Terkini Kegawatdaruratan Maternal dan Neonatal. Jakarta: CV Trans Info media.

Indriyani Diyan. (2013). Keperawatan Maternitas Pada Area Perawatan Antenatal. Yogyakarta: Graha Ilmu.

Jannah, R. 2017. Hubungan Kejadian Hiperemesis Gravidarum dengan Berat Badan Lahir Rendah Pada Ibu Bersalin di Wilayah Kerja UPTD Puskesmas Jaya Baru Banda Aceh.

Kementerian Agama RI, 2014. Al-Qur'an dan Terjemahnya Edisi Tajwid. PT Tiga Serangkai Pustaka Mandiri.

Marlin, D. (2016). Hyperemesis Gravidarum: Asesmen dan Asuhan Kebidanan. Scientia Journal unaja .

Marmi, dkk. (2010). Asuhan Kebidanan Patologi. Yogyakarta: Pustaka Pelajar

Masruroh, R. I. (2016). Hubungan Antara Umur Ibu Dan Gravida Dengan Kejadian Hiperemesis Gravidarum Di RSUD Ambarawa Kabupaten Semarang. MUSWIL IPEMI Jateng , 204-211.

Nadyah. (2013). Kegawatdaruratan Neonatal, Anak dan Maternal. Makassar: Alauddin University Press.

Mansjoer, Arif. 2014. Kapita Selekta Kedokteran. Jakarta: Media Aesculapius. 
Muhammad Abu. Diterjemahkan oleh Drs.Ahsin Wijaya dan Drs. Totok Jumanto dengan judul Al-Quran: Kesehatan dalam Islam “ Nilai Kesehatan dalam Islam”. Jakarta: Bumi Aksara, 2016.

Nisak Ana Zumrotun, W. A. (2018). Status Kadar Hemoglobin Pada Ibu Hamil trimester I Dengan Hiperemesis Gravidarum. Indonesia Jurnal Kebidanan Vol.2 No.2 , 63-68.

Nugroho Taufan. (2015). Patologi Kebidanan. Yogyakarta: Nuha Medika.

Norma Nita, Dwi Mustika. (2013). Asuhan Kebidanan Patologi. Yogyakarta: Nuha Medika.

Oktavia Lina. 2016. Metode Penelitian Dalam Kebidanan. Jakarta: Yayasan Bina Pustaka.

Octaviadon, A.D. 2017. Hubungan Dukungan Suami Terhadap Kehamilan dengan Kejadian Hiperemesis Gravidarum.

Octaviani, dkk. 2017. Hubungan Primigravida, Mola Hidatidosa dan Gemellli dengan Kejadian Hiperemesis Gravidarum Pada Ibu Hamil di Ruang Mawar RSUD dr. M. Yunus Bengkulu.

Prawirohardjo, Sarwono. 2014. Ilmu Kebidanan. Jakarta : PT Bina Pustaka Sarwono Prawihardjo

Puriati Ruri, M. N. (2014). Hubungan Paritas dan Umur Ibu Dengan Kejadian Hiperemesis Gravidarum Di RSUD Adjidarmo Rangkasbitung . Jurnal Obstetrika Scientia , 180191.

Putri, dkk. 2016. Hubungan Paritasdan Status Nutrisi dengan Hiperemesis Gravidarum Pada Ibu Hamil Trimester I di RB NH Kuwaron Gubug Kabupaten Purwodadi.

Rahma Marliana, S. T. (2016). Asuhan Pada Ibu Hamil Trimester I Dengan Hiperemesis Gravidarum Tingkat I. Midwife Jurnal Volume 2 No.02, 50-58.

Rahmawati, N.E. 2015. Ilmu Praktis Kebidanan. Surabaya: Victory Inti Cipta.

Rahmi, F. (2017). Pengalaman Ibu Dengan Hiperemesis Gravidarum Di Rumah Bersalin Sehat Bondar Kecamatan Tambusai Kabupaten Rokan Hulu. Jurnal Maternity and Neonatal Volume 2 No 2 , 192-200.

Rukiyah Ai Yeyeh, Y. L. (2010). Asuhan Kebidanan 4 (Patologi). Jakarta: CV. Trans Info Media.

Sarwono, P. (2014). ilmu kebidanan. Jakarta: Yayasan Bina Pustaka Sarwono Prawirohardjo.

Setiawati. 2013. Gambaran Karakteristik Ibu Hamil dengan Hiperemesis Gravidarum di Rumah Sakit Islam Sitti Khadijah Palembang.

Siwi, W. E. (2015). Asuhan Kebidanan Pada Kehamilan. Yogyakarta: Pustaka Baru Press.

Susilawati dan Erlina, "Hubungan Gravida, Umur, dan Pendidikan Ibu dengan Hiperemesis gravidarum”.Jurnal Obstetrika Scientia, 2017.

Syamsuddin Syahril, L. H. (2018). Hubungan Antara Gastritis, Stres, dan Dukungan Suami Pasien Dengan Sindrom Hiperemesis Gravidarum di Wilayah Kerja Puskesmas Poasia Kota Kendari. Jurnal Penelitian dan Pengembangan Pelayanan Kesehatan, Vol.2 No. 2 , 102-107.

Shihab, Quraish. 2015. Tafsir Al-Misbah. Jakarta: Lentera Hati.

Tri, A. (2015). Beberapa Determinan Penyebab Kejadian Hiperemesis Gravidarum Di RSU Ananda Purwokerto. Jurnal Involusi Kebidanan,60-73.

Umboh Salome Hertje, M. T. (2014). Faktor-Faktor Yang Berhubungan Dengan Kejadian Hiperemesis Gravidarum Di Puskesmas Tompaso Kabupaten Minahasa. Jurnal Ilmiah Bidan , 24-33.

Varney, H. 2007. Asuhan Kebidanan. Jakarta: EGC. 
Wiwik, dkk. 2017. Hubungan Pengetahuan dengan Sikap Ibu Hamil Dalam Mencegah Kejadian Hiperemesis Gravidarum di Wilayah Kerja Puskesmas Padalarang.

World Health Organization, (2013), Buku Saku Pelayanan Kesehatan Ibu di Fasilitas Kesehatan Dasar dan Rujukan. Jakarta: Bina Kesehatan Ibu.

Yenni. 2016. Metode Penelitian Kesehatan. Jakarta: Rineka Cipta.

Yusuf Namira, W. S. (2018). Faktor-Faktor Yang Mempengaruhi Kejadian Hipermesis Gravidarum . MaKMA Vol I No.2 , 94-100. 